\title{
Effect of Shot Peening Treatment on Forging Die Life
}

\author{
Shih-Hsien Chang ${ }^{1, *}$, Shih-Chin Lee ${ }^{2}$ and Tzu-Piao Tang ${ }^{3}$ \\ ${ }^{1}$ ASSAB STEELS TAIWAN CO., LTD., Taipei, Taiwan, 248, R. O. China \\ ${ }^{2}$ Department of Materials Science and Engineering, National Cheng Kung University, Tainan, Taiwan, 701, R. O. China \\ ${ }^{3}$ Department of Materials and Mineral Resources Engineering, National Taipei University of Technology, \\ Taipei, Taiwan, 106, R. O. China
}

The aim of this paper was to study the effects of die life through shot peening treatments on AISI H13 steel, and tests were performed to study the influential parameters of the shot peening process. To evaluate the effects of microstructure and the die life of AISI H13 steel after steel shot peening processes, we conducted and evaluated roughness tests, micro hardness and wear tests, and SEM microstructure inspections. The shot peening process was conducted under a pneumatic peening machine. Experimental results showed that $0.3 \mathrm{~mm}$ steel shots and 30 minutes at $451 \mathrm{kPa}$ of shot peening treatment was optimum for AISI H13 steel for improving wear resistance and the die life of steel. It enhanced the surface hardness to HV 561 and extended ability of the limit wear resistance for AISI H13 steel. Dislocation microstructure emerged on the steel surface by shot peening. In particular, this technology has been successfully applied to forging die, and is able to improve and extend the die life of steel 2 to 3 times. [doi:10.2320/matertrans.MER2007622]

(Received July 30, 2007; Accepted December 14, 2007; Published February 25, 2008)

Keywords: AISI H13 steel, steel shot peening, pneumatic peening machine, wear resistance, forging die

\section{Introduction}

Shot peening has been used for many years as a palliative on a number of problems affecting the surfaces of components in several industries. ${ }^{1)}$ The improvements of shot peening are produced by compressive stress and cold work combinations. Compressive stresses are beneficial in increasing resistances to fatigue failures, corrosion fatigue, and erosion caused by cavitation. ${ }^{2)}$ The cold work effects of shot peening treatments can increase the surface hardness of many materials. However, the shot peening process can be defined as work hardening to the surface of components, by means of propelled streams of spherical shots. It employs a steel shot media running at high speed to affect the material's surfaces, which results in a compressed and condensed surface. In shot peening, the surface layer of material yields plastically to residual compressive stress under the impact of shot peening. ${ }^{3-5)}$

Various metal forming processes are carried out at temperatures 0.5 times higher than the homologous temperature, and therefore, are considered hot working processes. Among them are die-casting, hot forging and extrusion molds. ${ }^{6)}$ Thermal gradients lead to dimensional variations, and generate stress and deformation. Thermal fatigue cracking is one of the most important life limiting tool failures known to hot work steels. ${ }^{7,8)}$ During the hot work steel processes, the die surface is rapidly heated and then quenched, thus resulting in a decrease of surface hardness and toughness. Besides, the higher residual tensile stress is proven useless during the cold forging process, whereas shot peening induced compressive stress is helpful in eliminating tensile stress.

Shot peening has long been widely used as a low cost, simple method for increasing fatigue and wear resistance of materials. Through shot peening, negative production induced influences, such as surface decarburization, roughness,

*Corresponding author, E-mail: technical.abp@assab.com.tw and tensile stress are balanced. ${ }^{9)}$ The aim of this paper was to study the effects of wear properties and the die life of shot peening treated on AISI H13 steel, as well as to identify the influential parameters of the shot peening process. H13 specimens used in this study were 47 to 48 HRC after hardening and tempering treatments. The shot peening process was conducted under a pneumatic machine. Cast steel shots with hardness of 45 to 48 HRC and 3 different diameters were used under variable pressures and peening times. All tests were conducted to evaluate the wear properties and the die life of shot peening treatments for this material.

\section{Experimental}

In this study, there were many parameters to be kept under shot peening process control. These are the peening coverage, saturation, shot material, shot size, pressure, and peening time. The purpose of this experiment was to clarify the effects of different shot media, peening times, and the optimal pressure for shot peening on AISI H13 steel, and their influential parameters. The shot peening process was conducted under a bucket-type enclosed and pressurized pneumatic machine, using different sizes of cast steel shots with hardness ranging from 45 to $48 \mathrm{HRC}$, and applied under different pressures and times. During this process, the nozzle diameter of shot peening machine was $6 \mathrm{~mm}$, the working distance kept $250 \mathrm{~mm}$, and the required peening coverage was over $200 \%$. The different diameters of the steel shots used were $0.3,0.5$, and $0.7 \mathrm{~mm}$. Premium quality AISI H13 tool steel was used throughout this study. The specimens were austenized at $1020^{\circ} \mathrm{C}$ for 50 minutes, then nitrogen quenched by vacuum furnace, tempered at $590^{\circ} \mathrm{C}$ for 3.5 hours; this process was repeated 3 times in order to obtain a hardness of 47 to 48 HRC. The chemical composition (mass $\%$ ) of the AISI H13 steel was as follows: $0.39 \% \mathrm{C}$, $1.0 \% \mathrm{Si}, 0.4 \% \mathrm{Mn}, 5.2 \% \mathrm{Cr}, 1.4 \% \mathrm{Mo}$ and $0.9 \% \mathrm{~V}$.

Microstructure, hardness inspections, intensity and wear 


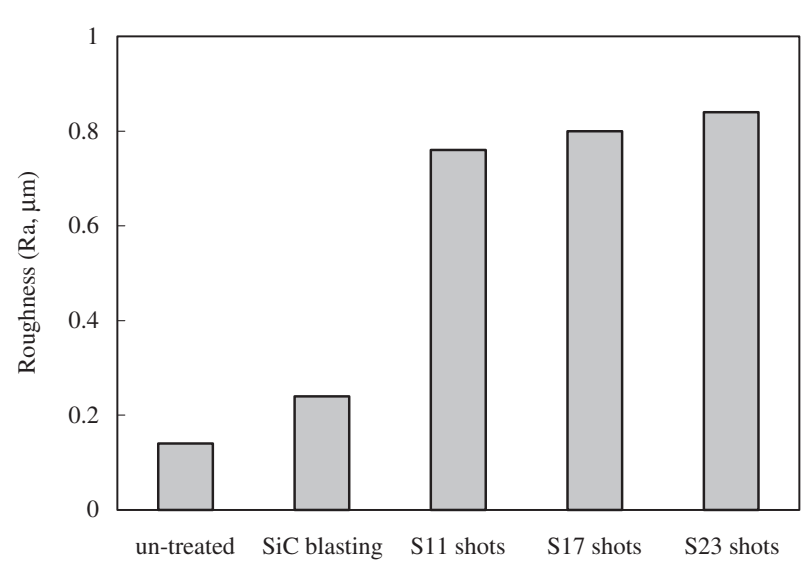

Fig. 1 Comparison of surface roughness for shot peening treatment at different media for AISI H13 steel.

tests of the AISI H13 steel were conducted at room temperature in order to compare the effects of un-treated and shot peening treated steel. Intensity of shot peening was measured by an Almen gauge, and checked by using the standard A-strip. Sliding wear and friction wear tests were carried out under a wide range of conditions using pin-ondisc (ASTM G99). During the wear test, the loading weight was kept at $10 \mathrm{~N}$; slide speed was $0.3 \mathrm{~m}$ per second, pin-ondisc employed a Cr steel ball and with hardness of HV 680. Finally, optimal process conditions were used on cold and hot forging molds to evaluate the performance of this procedure.

\section{Results and Discussion}

The aim of this paper was to evaluate the die life of AISI H13 after shot peening process. Figure 1 shows the surface roughness of different media and size of shot peening treatments for AISI H13 steel. After the grinding process, the roughness of an un-treated specimen was $0.14 \mu \mathrm{m}$. Normally, a blasting process was used to clean the surface of a mold, however, this was not helpful to increase the hardness or improve the microstructure of AISI H13 steel. In this study, $\mathrm{SiC}$ powder was used to compare the intensity of steel shots. The blasting process slightly increased the roughness of material, but the effect was insignificant. The roughness of specimens increased as the diameter of the steel shots increases. S11, S17 and S23 represent the diameters of $0.3,0.5$ and $0.7 \mathrm{~mm}$, respectively. Generally, the minimum required roughness for forging molds was $1 \mu \mathrm{m}$. In this experiment, the surface roughness of different steel shots were all below this value.

In order to measure and calibrate the peening impact energy, J. O. Almen of General Motors Research Lab. developed a method utilizing Almen strips. The peening process can cause the Almen strip to curve and convex on the peened surface. The height of this curvature when measured in a standard Almen gauge is called the intensity of arc height. ${ }^{2}$ ) Figure 2 shows the intensity of shot peening treatments at different pressures. The intensity specimens were measured by A-strips and Almen gauge after exposed 30 seconds, while the steel shot size remained $0.3 \mathrm{~mm}$. Increasing the pressure of the shot stream caused a rapid

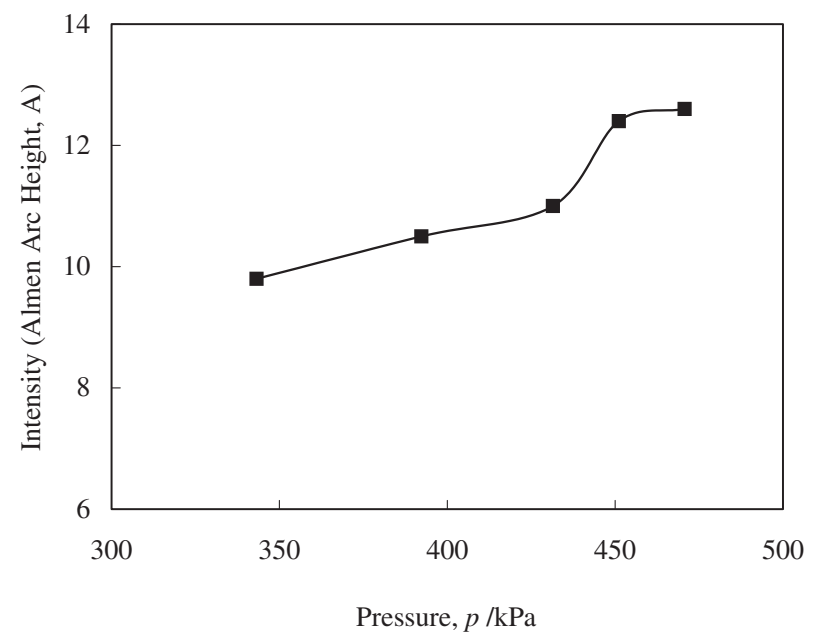

Fig. 2 Comparison of intensity for shot peening treatment at different pressure for Almen A-strips.

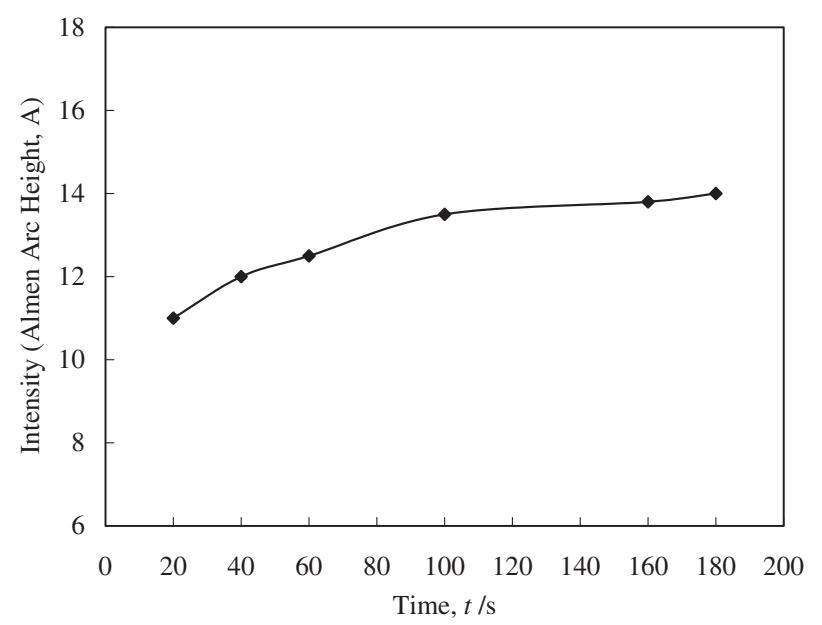

Fig. 3 Comparison of intensity for shot peening treatment at different peening times for Almen A-strips.

increase to approximately $451 \mathrm{kPa}$, then the increase slowed down and gradually moved toward saturation at $470 \mathrm{kPa}$. The depth of the compressive layer was proportional to the Almen intensity. ${ }^{1,2)}$ Higher intensity represents greater compressive stress after peening. The shot peening pressure was kept at $451 \mathrm{kPa}$, the steel shot used $0.3 \mathrm{~mm}$, and then the peening times was gradually increased for the shot peening treatments. The intensities at different peening times were compared, as shown in Fig. 3, which indicate that the intensity of Almen Arc Height was increased as the times of shot peening treatment increases. These results clearly show that the intensity reaches the maximum saturated value after 3 minutes of shot peening.

Shot peening induces residual compressive stress on the surface, but does not considerably increase hardness or decrease toughness, unlike thermal treatments, such as carburizing or inducting hardening. ${ }^{1)}$ In this study, wear testing employed sliding wear and friction wear tests, under a wide range of conditions using pin-on-disc (ASTM G99). During the wear test, the loading weight was kept at $10 \mathrm{~N}$, slide speed at $0.3 \mathrm{~m} / \mathrm{sec}$; the rotational diameter was $21 \mathrm{~mm}$, 


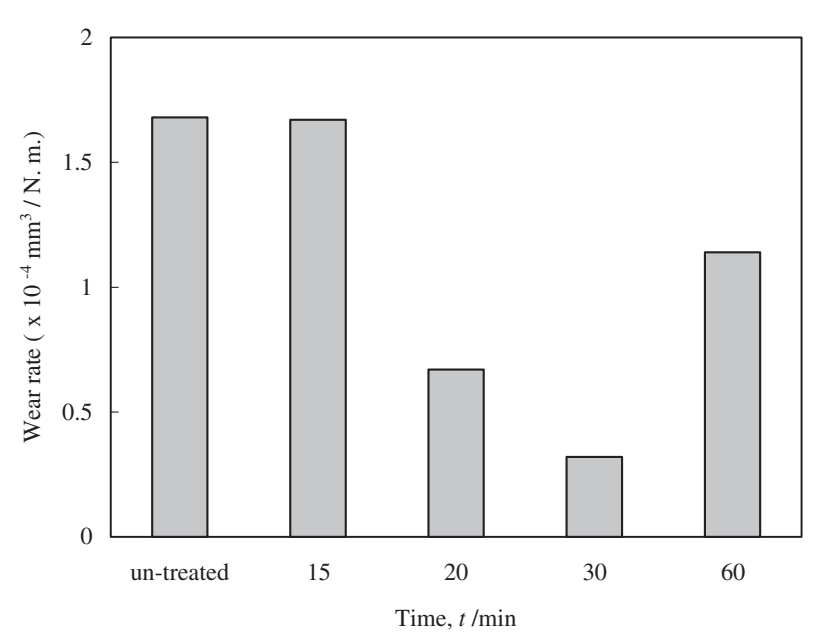

Fig. 4 Comparison of wear rate for un-treated and after shot peening treatment at different peening time for AISI H13 steel.

and the pin ball used Cr steel with a hardness of HV 680 and a diameter of $6.3 \mathrm{~mm}$. The wear resistance was very much related to the time of shot peening treatment; too short or too long for peening time proved ineffective for wear resistance.

Comparison of the wear rate of un-treated and treated at different peening times for AISI H13 steel is shown in Fig. 4. Increasing the time of shot peening treatment will lead to more effectually work hardening. ${ }^{1,2)}$ Due to the surface of H13 steels have not yet completely reached work hardening before 20 minutes. The suitable time of shot peening on forging die is $20 \sim 30$ minutes. In this study, the optimal wear rate appeared obvious at 30 minutes. The wear rate of the untreated specimen was $1.7 \times 10^{-4} \mathrm{~mm}^{3} / \mathrm{N} . \mathrm{m}$, and the optimal shot peening treated was $3.2 \times 10^{-5} \mathrm{~mm}^{3} / \mathrm{N}$.m. The average frictional coefficient of the un-treated specimen was 0.21 , and shot peening treated was 0.16 . With regard to the un-treated specimen, the wear coefficient was increased rapidly after slip $500 \mathrm{~m}$. However, after the optimal shot peening treatments the increase of wear coefficient slowed after slip $1100 \mathrm{~m}$. This indicates the ability of the shot peening treatment to enhance the wear resistance for AISI H13 material. By increasing the surface hardness through the shot peening process and decreasing the friction coefficient, the wear resistance of AISI H13 steel was enhanced.

Benefits of shot peening by cold work include work hardening, surface texturing, and closing of porosity. ${ }^{2)}$ Figure 5 shows the surface hardness and microstructure of a cross-section of AISI H13 steel under optimal shot peening treatment. During the optimal process, the air pressure was kept at $451 \mathrm{kPa}$, the steel shots used were $0.3 \mathrm{~mm}$, and the peening time was 30 minutes. The surface hardness increased significantly, thus reducing the risk of surface defects leading to fatigue cracking. Surface hardness and depth of the compressive layer was affected by variations in shot peening treatment parameters. In this experiment, the effected area ranged from 0.07 to $0.1 \mathrm{~mm}$. The surface hardness reached HV 561 after optimal shot peening, which was obtained by cold work and induced hardening and surface texturing of the microstructure of AISI H13 steel. It was proven that the shot peening can induce plastic deformation of the exposed surface layers, thus resulting in the slip bands and dislocation

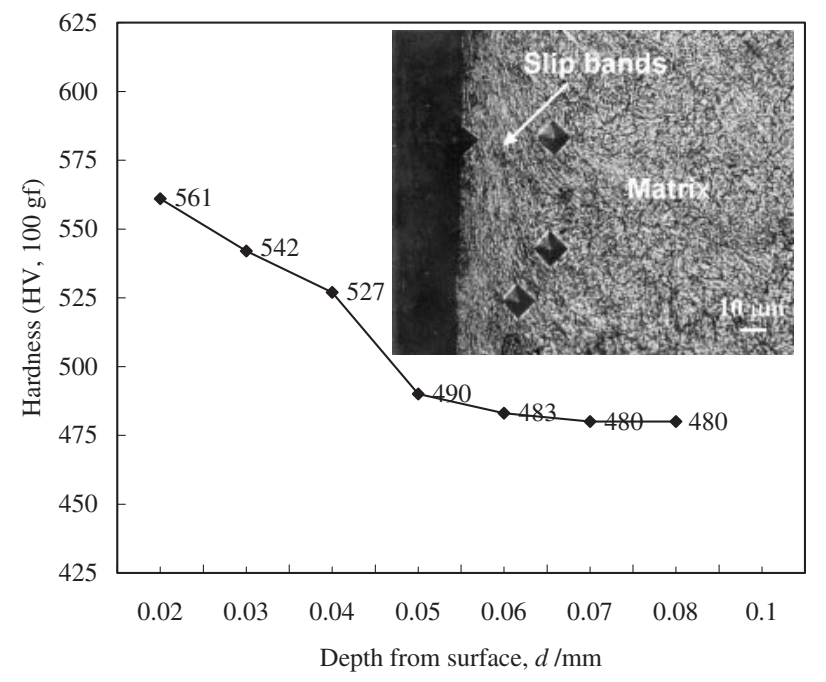

Fig. 5 Surface hardness and optical micrograph of cross-section of AISI H13 steel after optimal shot peening treatment.

structure on the surface of material. ${ }^{10,11)}$ In this study, slip bands was also found on the surface of AISI H13 steel after shot peening treatments, which could improve the wear resistance and increase the fatigue strength of the material.

Figure 6(a) shows the SEM micrograph of the EDM surface of AISI H13 steel, many defects and cracks can be found on the surface of the steel. The cracks of the EDM layer were damaged in the molds during production; most of the ruptured sources originated from the mold are in the EDM layer, as shown in Fig. 6(b). Therefore, a polishing process was necessary to reduce the roughness. ${ }^{12-14)}$ Shot peening treatments can simultaneously form a condensed and more uniform structure on the surface, which improves surface defects of materials, as shown in Fig. 6(c). There were many well-distributed pits of structure on the material surface are caused by shot peening treatment. As shown in Fig. 6(d), when combined with the blasting process, there are no EDM layers or defects existing on the surface of the steel. Shot peening treatment is concluded at high pressure and speed, and able to offer a condensed and uniform microstructure, increases the surface hardness of the material, and eliminates the surface defects.

Shot peening treatment can increase the surface hardness and reduce the possibility of surface defections that would result in fatigue cracking. The process has been successfully applied on both cold and hot forging molds to improve wear resistance and extend the die life, as shown in Fig. 7. Higher residual stress remaining on the surface of forged molds shortens the die life span, whereas shot peening induces the residual compressive stress to improve the fatigue strength and fatigue life of molds. Figure 7(a) shows the appearance and die life of cold forging molds before and after optimal shot peening treatment, which are 4 60,000 shots and over 120,000 shots respectively, as shown in Fig. 7(b). Similarly, Fig. 7(c) shows the appearance and die life of hot forging molds before and after optimal shot peening treatment, which are 1 15,000 and over 25,000 shots respectively, as shown in Fig. 7(d). The experiments have proven that the optimal shot peening treatment can increase the die life for cold forging by over 3 times, and hot forging molds by 2 times. 
(a)

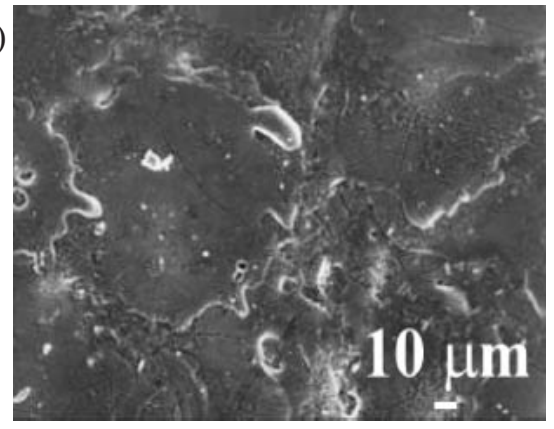

(c)

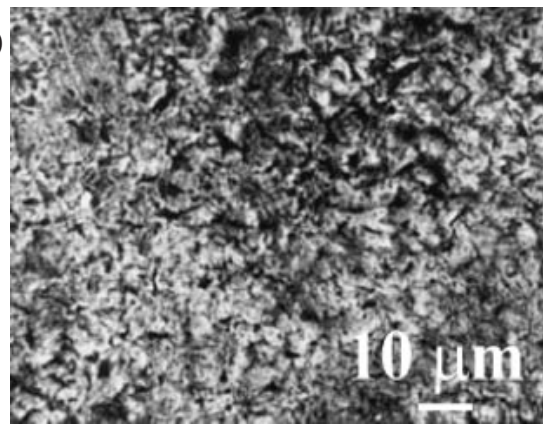

(b)

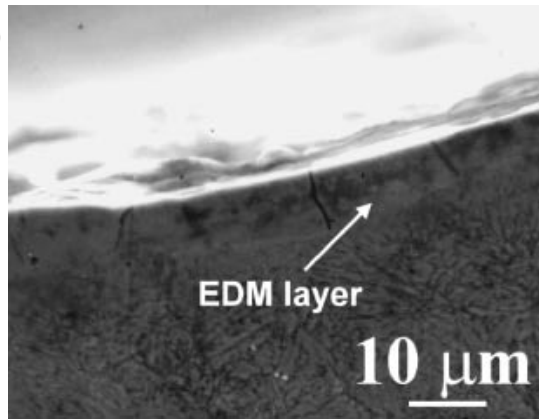

(d)

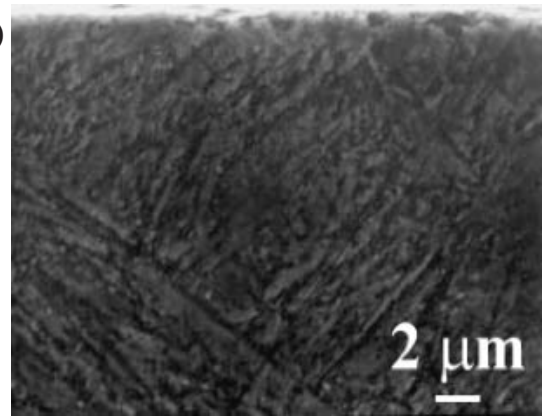

Fig. 6 SEM micrographs of AISI H13 steel by different treatments; (a) surface, and (b) cross-section of E.D.M surface; (c) surface; and (d) cross-section of shot peening.

(a)

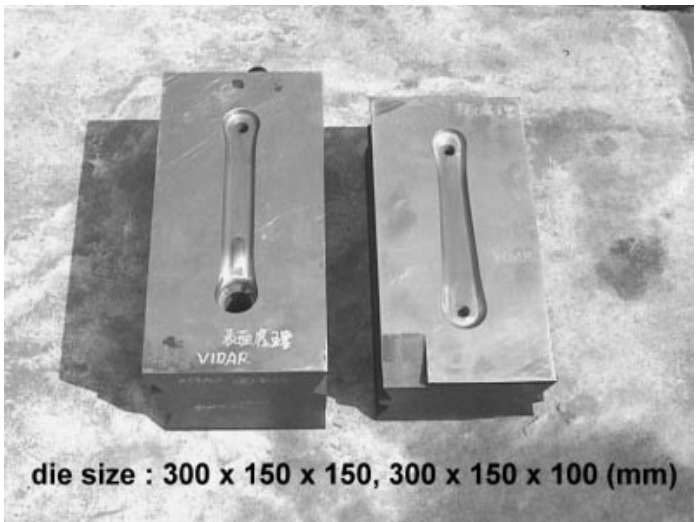

(c)

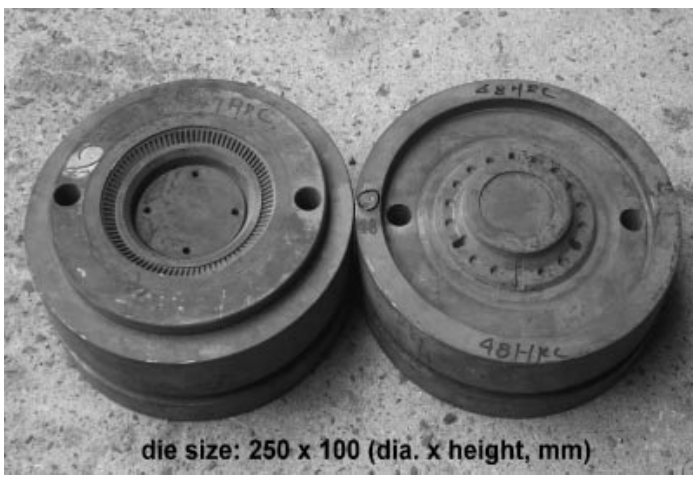

(b)

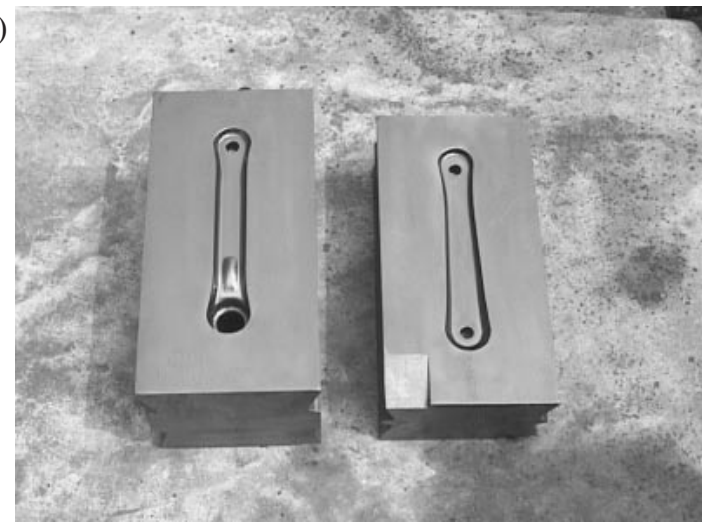

(d)

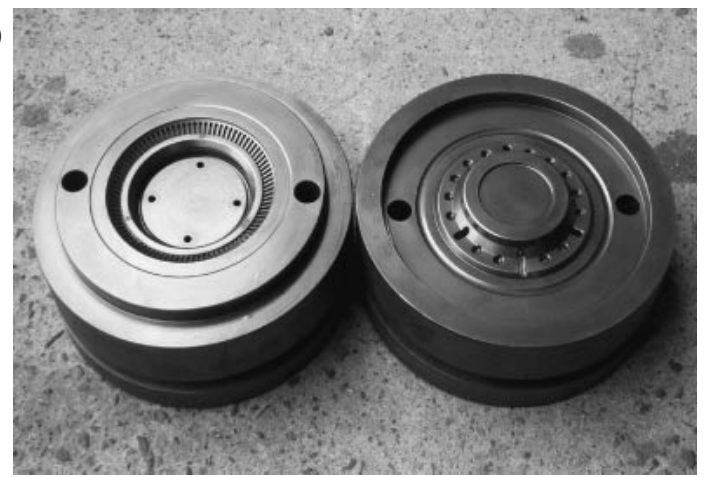

Fig. 7 Shot peening applied to AISI H13 molds to extend the die life; (a) before, (b) after shot peening of cold forging molds; and (c) before, (d) after shot peening of hot forging molds.

\section{Conclusion}

(1) Shot peening can improve the wear resistance and microstructure of AISI H13 steel. It can decrease the wear rate and wear coefficient of material, then result in a more condensed and dislocation structure on the surface.

(2) The process has been proven and successfully applied to cold and hot forging molds to extend die life. In this study, the optimal shot peening treatment increased the die life for cold forging by over 3 times and hot forging molds by 2 times. 


\section{Acknowledgments}

This research was supported by ASSAB STEELS TAIWAN CO., LTD. The authors would also like to express their appreciation for Dr. Harvard Chen.

\section{REFERENCES}

1) K. J. March: Shot Peening Techniques and Applications, (Engineering Materials Advisory Services Ltd., 1993).

2) Metal Improvement Company, Inc.: Shot Peening Applications, 8th edn, (2001) pp. 6-50.
3) S. Tekeli: Mater. Lett. 57 (2002) 604-608.

4) M. Kobayashi, et al:: Int. J. Fatigue. 20 (1998) 351-357.

5) S. Wang, et al.: J. Mater. Process. Technol. 73 (1998) 64-73.

6) C. M. D. Starling and J. R. T. Branco: Thin Solid Films 308-309 (1997) 436-442.

7) A. Srivastava, et al:: Surf. Coat. Technol. 163-164 (2003) 631-636.

8) A. Persson, et al:: Surf. Coat. Technol. 191 (2005) 216-227.

9) V. O. Abramov, et al.: Ultrasonics. 36 (1998) 1013-1019.

10) T. Dorr and L. Wagner: ISCP-6 (1996) pp. 174-183.

11) Z. G. Liu, et al.: Mater. Sci. Eng. A 375-377 (2004) 839-843.

12) H. J. Kim and J. F. Wallace: Surf. Eng. 10 (1994) 56-64.

13) G. H. Farrahi and H. Ghadbeigi: J. Mater. Process. Technol. 174 (2006) 318-324.

14) A. Inoue, et al:: Mater. Trans., JIM 44 (2003) 2391-2395. 